\section{A Revised Devonian Pole for Britain}

Paleomagnetic surveys of Devonian rocks from Great Britain have been carried out on the Old Red Sandstone rocks from the Anglo-Welsh Cuvette ${ }^{1}$, and on Lower Devonian lavas from the Midland Valley of Scotland ${ }^{2}$. Two well-defined but significantly different axes of magnetization were obtained (Fig. 1). These will be referred to as $A$ and $B$; the corresponding pole positions are situated at $159^{\circ}$ E. $30^{\circ}$ N. and $130^{\circ}$ E. $10^{\circ}$ S., respectively.

The problem of which of these results indicates the true Devonian field, or whether perhaps both do, has puzzled workers in palæomagnetism for a number of years; for both appearod equally valid. There are two plausible explanations: (1) The pole may have undergone relatively rapid changes in its position during the Devonian; (2) the magnetization of the Old Red Sandstone may be younger than the rocks themselves. It is not our purpose now to discuss the relative merits of these, but to report the results of progressive thermal demag. netization experiments, which are relevant to the third explanation.

It can frequently be established beyond reasonable doubt that lavas acquire their primary magnetization when they cool down so that their magnetic age is the same as their geological age. This cannot be proved for sediments, the magnetization of which may be chemical in origin and therefore could be younger than the rocks themselves. The thermal demagnetization experiments were carried out on samples from the steeply folded Old Red Sandstone beds in Pembrokeshire, and the flat-lying formations in Brecon Beacons. The results showed that for all sites samples could be found which had two distinct components of magnotization: (1) A dominant component in the direction of $A$, which has a Curio point of $575^{\circ} \mathrm{C}$ and is therefore due to magnetite; (2) a weaker component in the direction of $B$, which has a Curie point of $675^{\circ} \mathrm{C}$, and is therefore due to hæmatite.

Application of the fold test shows that component (2) was acquired before folding and component (I) during or after folding. Since the folding is Hercynian, component (2) is likely to be of Devonian age and component

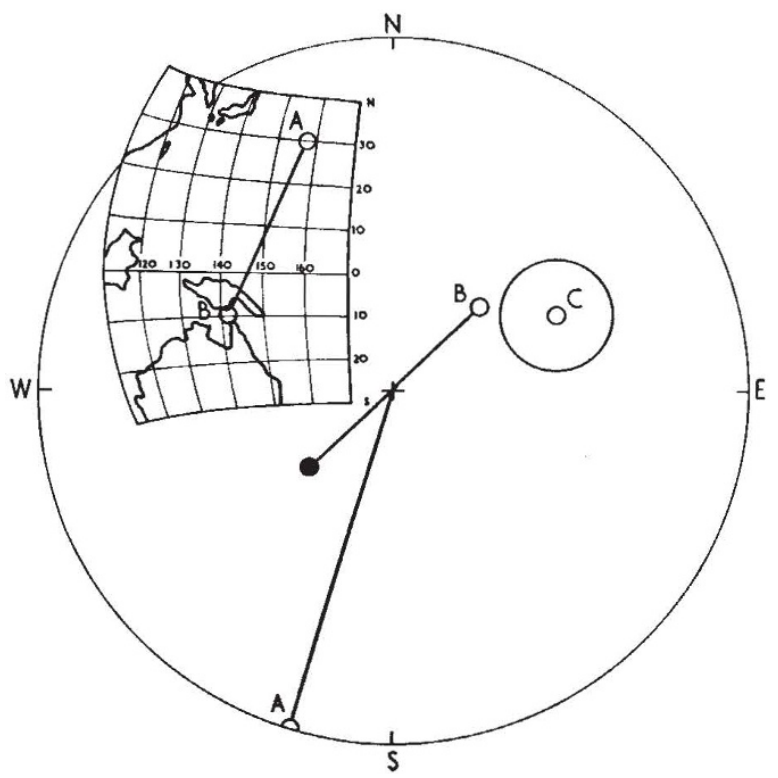

Fig. 1. A, Mean direction of magnetization of the Old Red Sandstones from the Anglo-Welsh Cuvette; $B$, mean direction of magnetization for the Lower Devonian lavas; $C$, mean direction of the Old Red Sandstones from the Anglo-Welsh Cuvette after heating to $600^{\circ} \mathrm{C}$ and cooling in zero-field. Open circles indicate upward inclinations, elosed circles indicate downward inclinations. Inset shows the corresponding pole positions
(1) may be of Permian age. This conclusion is supported by the two following observations: first, direction (1) is very close to the Permian direction ${ }^{1}$, and secondly, direction (2) agrees well with Stubb's result for the Lower Devonian lavas (Fig. 1).

It therefore seems that a strong magnetization could have been superimposed on a weaker Devonian mag. netization by the Permian field in the case of Old Red Sandstones of the Anglo-Welsh Cuvette. The discrepancy between the two Devonian pole positions is explained on this interpretation of the results of the thermal demagnetization experiments, and we suggest therefore that direction $B$ should be considered as the more reliable estimate of the Devonian field for Britain. It has been previously pointed out ${ }^{2}$ that if direction $B$ is accepted as giving the true Devonian pole, a strong retrogressive discontinuity is produced in the British polar wandering eurve.

However, palæomagnetic work in the U.S.S.R. principally on red beds, both east and west of the Urals ${ }^{3}$, yields a pole in agreement with the pole of $A$, and not with that of $B$, which the foregoing experiments have led us to prefer to accept as the Devonian pole. It would be interesting to see whether similar heating experiments on the Russian red beds reveal likewise a small component of magnetization in tho direction of $B$.

\section{F. H. Chamalaun} K. M. Creer

Department of Physics, King's College,

Newcastle upon Tyne.

${ }^{1}$ Creer, K. M., Phil. Trans. Roy. Soc., A, 250, 111 (1957).

2 Stubbs, P. H. S., thesis, Univ. London (1958).

${ }^{3}$ Kalashnikov, J., Acad. Sci. U.S.S.R., Geophys. Ser., No. 9, 1243 (1961).

\section{GEOLOGY}

\section{Upper Jurassic Rocks Beneath the Bristol Channel}

THE first results from a geological survey of the floor of the Bristol Channel, carried out during the spring of 1960 , have already been reported ${ }^{1}$. Jurassic rocks were found "from the Holms westwards to beyond Ilfracombe" which were thought to be of Liassic age, but macrofaunal evidence was scanty and no estimate could be made of the extent of the Jurassic sequence.

Subsequent micropalæontological investigations of selected samples largely confirmed these first results. The foraminiferal faunas from the eastern part of the Channel indicated horizons from the Angulatum to Raricostatum Zones of the Lower Lias (Hettangian-Sinemurian). To the north-west of Ilfracombe there were, in addition, indications of Lower Pliensbachian rocks. The overall appearances of these faunas were remarkably similar to those described and figured by Bartenstein from northwest Germany ${ }^{2}$ and permitted age-determinations at the sub-stage level. For the recognition of zones, however, it was necessary to identify variants within the 'Lingulina tenera' and 'Frondicularia sulcata' plexi, as described by Barnard $^{3,4}$.

In this first suite of samples there were two which yielded totally unexpected faunas. The first, taken between Morte Point and Worm's Head, yielded a large and varied assemblage characteristic of the Mutabilis Zone of the Kimmeridgian. The second, from a point some 15 miles to the east, contained a typically Lower Oxfordian assemblage. Further samples from this critical area, taken by R.R.S. Discovery II in May 1962 , contained foraminiferal faunas which confirmed the occurrence of Upper Jurassic rocks and revealed the presence of the Middle Jurassic as well.

In the present state of our knowledge the following conclusions can be drawn. The syncline found by Asdic and 